（大阪府立大学工学部后用化学科，堺市・神戸海洋気魚台才，神戸市生田区）（昭和 30 年 7 月 14 日受理）・

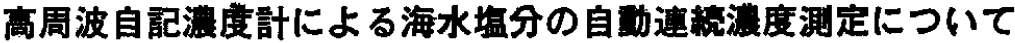

\author{
武者宗一郎・宗森 信・伊藤 三夫・武田 正巳 \\ 中村昌一郎・井上 悦夫・川本 㱬雄十・北村 弘行†
}

\section{1. 緒}

海洋学にわいて，塩素量*の測定は水温とともに海水 の密庭を導田するために必要であると同時に，塩素量そ のひのが海洋の特性として取报われ，海洋観測にわける 基本要素としてきわめて重要な位置を占めている。この $\mathrm{Cl} \%$ の測定にはつ枚に試料の採取と 化学分析操作のわ ずらわして技術手段を必要とし，また武料探取から結果 を洪定するまでの時間的焦れが結果の有效性という問䦩 に大きな障害を与えている。てれらの障害に处する他の

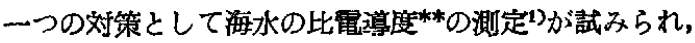
Pollak ${ }^{2)}$ 亿文って海永の温度と $k$ 被数とする一つの 関保式が $\mathrm{Cl}$ \% に対して与えられた。てれよりさきに Jacobson ${ }^{3)}$ は海水の塩分量***，温度，およひ㳭さの測 定操作に付随する時間的遅れを除くため，連続的な測定 記録を試み温度と $k$ の測定操作間にサーボ機構を探用し て実際的な検討を行い，それら結果の即時的な活用性を 強調している。てれらの澌定はすべて比電導度法である ため漫清電極の使用を余儀なくされている。そのため污 秛による Cell 定数の变動，機械的な棈造等に対して煩 蓶な考磨をはらう必要がある。また Jacobson はニッケ

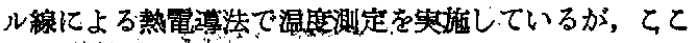
汒を機峨的制限が大きく加わって来ると考兄られる。著 者らがさきに報告した高周波洤度計りを海水の塩分連続 測定に適用すれば上述の上うな困難が幾分です楥和され ると洘え，外洋に比し河川水の流入等に上って塩公濃度 の変化が激しいと思われる大阪湾を対照として央験を武 みた。なお，実験当日の畏天候条件と実駼回数の制限の ため精密な数值的結論を得るに至らなかったが，得られ た記録結果は従来の測定加予想されるものと大体よく

* ผ上下 Cl禹と款す。

* 以下 $k$ と楁す.

*** 以下 $\mathbf{S} \%$ と款す.

1) Wenner, Frank, E. H. Smith, F. M. Soule, J. Res. U. S. Bur. Standards Paper No. 223, 5, 711 (1930): T. G. Thompson, H. E. Wirth, J. Cons. int. Explor. Mer, 6, 232 (1931): B. D. Thomas, T. G. Thompson, C. L. Utterback, ibid. Mer, 9, 28 (1934).

2) M. J. Pollak, J. A. Marine Research 13, 228 (1954).

3) A. M. Jacobson, Trans. Amer. Inst. elect. Engrs. 67, 714 (1948).

4) 武者, 矢野, 武田, 和田, 工化 58, 482 (1955); 被者, 武田, 和 田, 并上, 工化 58, 486 (1955).
一致している。

\section{2. 高周波塩分灌度㖕の適用性に 対する考察}

海洋学的に海水の $k$ は $\mathrm{Cl} \%$ と温度の函数として与兄 られる Thomas の表を基礎とするととによって得られ るが, Wenner らはての表に含まれる諮差が $\mathrm{Cl} \% の$ みを变数とせず総猵分としての $\mathrm{S} \%$ を变数とするて とによって滅少し得るととを提示した。との考察より Jacobson は 20 40\%の S\%を 0.3\% 以下の諮差範 四内で連続記録測定した。また他方 Poliak は Thomas

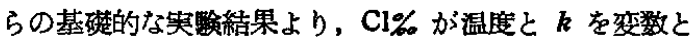
する一つの実験式を揫導し 61 個の武料について検討し， た結果 $\mathrm{Cl} \%$ が 0.005\% 以下の誤差以内で測定できる ことを示した。もし Kundsen によって確立された Cl\%

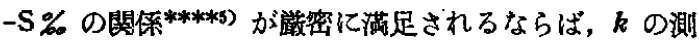
定と同期的な温度測定を並行するととによって必要誤差 領囲内で $S \%$ の測定炣能と考えられる。以上二つの 報告のように $k$ の測定により， $\mathrm{Cl} \%$ あるいは $\mathrm{S} \%$ の決 定が滿足されるならば従来低周波数の交流を用いる電尊 度洗とおおよそ同じ機構であるとてろの高周波電導度法 が適用し得ると考える。さらに本法によれば海水中の無 機塩類以外の物質 (たとえば有機物, および微細な固形 物等)の筫荷にも独特，鋭敏な検出性能を期待し得る。本 法の湘定操作が簡便であるという点において Jacobson その他の電導度法と大美ないかも知れないが，間接電極 を用いるための多くの利点が期らかにされるであらう。

\section{3. 実 検 装}

\section{1. 栻料海水の採水回路}

海水豇料は船の右䑨側，静止海面下 $1 \mathrm{~m}$ の位置に探 取口として 1/2 时鉄管の開口を設け，甲板に 1/4 馬力

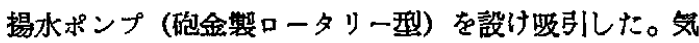
泡の影響を少なくするために試料検出用コンデンサーは 海面とポシプとの間にとりつけ，吸引した海水はポンプ の排出孔より流出せしめ必要の都度分析武料を採取する。

**** $S\left(\%_{*}\right)=0.030+1.8050 \mathrm{Cl}\left(\%_{6}\right)\left(\mathrm{Cl}=3\left(\%_{6}\right)\right.$ 以上の期合)

5) 三宅, “海洋化学” 化学実跧学第一部地球化学, 河出害展. 


\section{他は海中にすてる。}

\section{2. 高周波沙度䚺}

既報》の装置をそのまま船上観湘室に設置使用した。 記録計はフルスケール $500 \mu \mathrm{A}$ ，記録紙移動速率 $600 \mathrm{~mm}$ $/ \mathrm{hr}$ である。観测船の船速は 8 ノットであるから約 $4 \mathrm{~m}$ / sec である。検朋用コンデンサ一部における 海水試料 の流速は $5 \mathrm{~m} / \mathrm{sec}$ である。また記録紙上のペンの太さ (約 $0.7 \mathrm{~mm}$ ) の门は海面の約 $17 \mathrm{~m}$ に相当するので, 鹳 録結果は海面の約 $17 \mathrm{~m}$ 每における測定值を連続的かつ 平均的に示していると考えてさしつかえない*。

\section{3. サーミスター温度計}

サーミスター温度計は感度を大とするため常温におい て約 $500 \mathrm{k} \Omega$ の抵抗值を示す element を用いた。既笮の ものと同しくサーミスター elementをブリッシの一过に 持つ double ブリッシの真空管電圧棓に組んだものであ

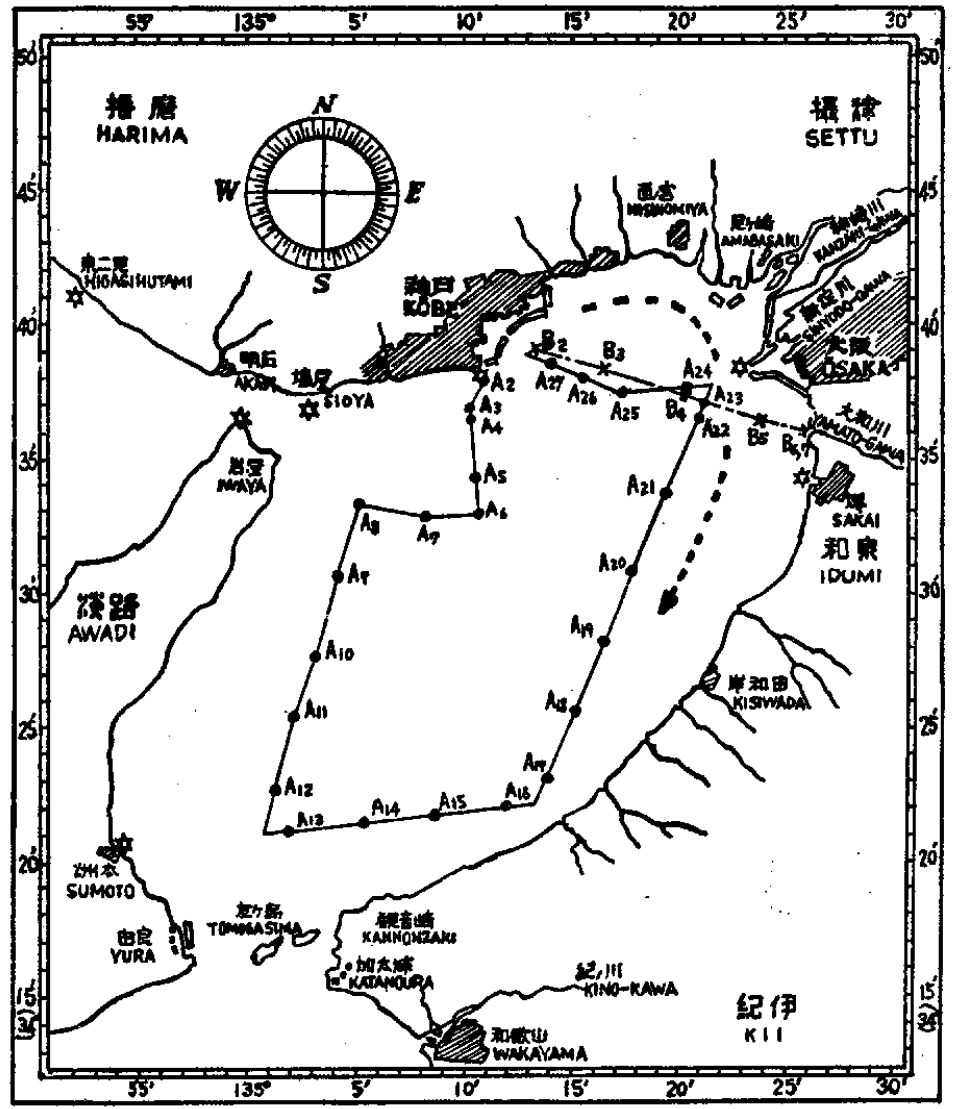

大阪湶

第 1 図航 跡 図
る。測定温度籍团は任意に調節し得るが予想される海水 の温度变化範囲を対照として $14.30^{\circ} \sim 20.60^{\circ} \mathrm{C} /$ フルス ケールとした。温度に対する指示感度は $1.05^{\circ} \mathrm{C} / 1.0$ ス ケール**および応答に対する時定数は約 40 秒である。

\section{4. pH メーター}

pH の測定を並行して行うべく，柳本製のガラス電極

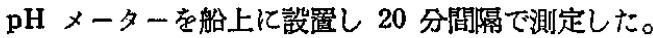

以上の高周波濃度計，サ一ミスタ一温度計， $\mathrm{pH} メ ー$ ターの電源は 船内の AC $110 \mathrm{~V}$ 幹線より鉄共振型の安 定装置を経て供給した。

\section{4. 実 験 操 作}

3 において述べた実験装置を神戸海洋気象合観测船春 風丸（約 150 トン）に積載装備し，2 日間にわたって大 阪湾の海水について実験を行った。その航跡を第 1 図に 示す。AおよびBの番号は試料の採 取地点を示し，A 约第1日（昭和29 年11月17日）で午前 8.5 時神戸港を 出航し全コースる約 9 時間で航海し た。Bは第 2 日（昭和 29 年 11 月 18 日）のものを示し午前 8.5 時神戸港 を田航し，堺市大和川沖約 $1 \mathrm{~km} の$ ところまでの直線コースを航行後約 3 時間停船し，潮位による変化を観 測した。 $\mathrm{Cl} \%$ 榆定用弑料は 20 分間 隔で採取ビンに探取し、だ゙゙ちに 測定後密程保管した。上陸後 $\mathrm{Cl} \%$ は 常法によって求めた。また試料採集 中は高周波濃度計，サーミスター温 度計ともにチェック回路に切換え， 装䀠の安定性を記録検查した。

\section{5. 実験結果および考察}

\section{i ）高周波濃度計指示***の機械} 的铞差

高周波濃度計の検出端子の物遇的

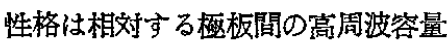
の変化を検汇成分としているのであ るから，気泡としての空気の影響が 大きく現われるととが拈党られる。 第 2 罒はその影響を示し記録結果は すでに1本の巾のある帯となって現
＂試料流速〉船速なるため。

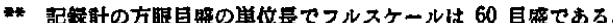

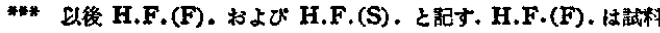
が流场している揭合，H.F.(S). 性停止している揭合を表わす. 


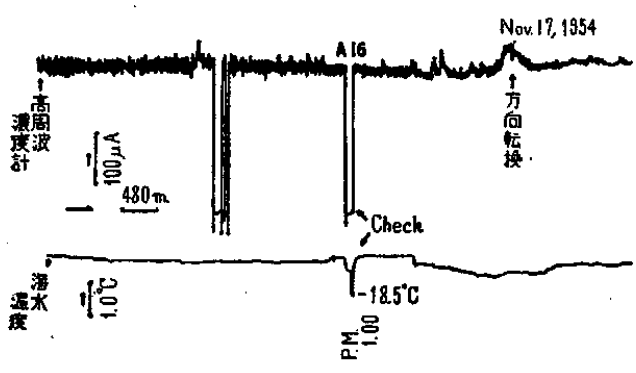

（爻泡の混人抢よび方向転換による悎性の作用）

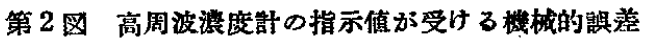

われている。以上の結果より気泡の混入に対しては十分 なる洘慰を必要とする。との気泡は洲本沖より東准中 $19 \mathrm{~m}$ の風隹あおられたため，船がピッチングとローリ ングを起し舴側で生じた泡の中細かなもののみがポンプ にそのまま吸引せられたものである。また第 2 园を見る と船の方向転換によるペンの慣性による運動が記録に現 われている。第2因には A-16 と A-17 の間における ものを示しているが，他の場合にも同様の記録が得られ ている。このてとは船の急速な方向転換によって起る横

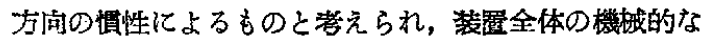

設置方法に㥀重な考臀を必要とする。ピッチング，ロー リングも同じような影筫を示すからぺン重量はなるべく 軽小なものを用うべきである。

\section{ii) $\mathrm{Cl} \%$ と H.F. (F).の䦐}

各地点にての探取試料の $\mathrm{Cl} \%$ と記録紙加ら就みとっ た H.F. (F). および水温ななびに静的に測定された $k$, pH, H.F.(S). の対比を第3 函に示した。横軸は第 1 四に示している。第3四よりわかるように $\mathrm{Cl} \%$ と H.F.(S). は全体にわたって長好な比例性を示している が，動的に連続記録された H.F.(F). の指示は A-23， 24 付近で大きく(+) の方向に 増加している。試みに ての付近の $\mathrm{S} \%$ 実験的に求めて見たところ A-23, 24 および 25 においてはそれぞれ 25.39，27.49およ び 24.86 となって相刘的に大きな変化は見られず，採 取後相当時間的経過を経た後に测定された H.F.(S). の值および $k$ が良い比例性を示すとと，およびB武料に おいては全股的にそれぞれがかなり良好な比例関係にあ るてと等より推測して，㭙間的経過に応してその状態の 变化をきたす有機物か，あるい性細な固形物の混入等 が考えられる。また $k$ の值が部分的に特異な攧を示すこ とは，その測定が後日行われたために気象条件*を異に
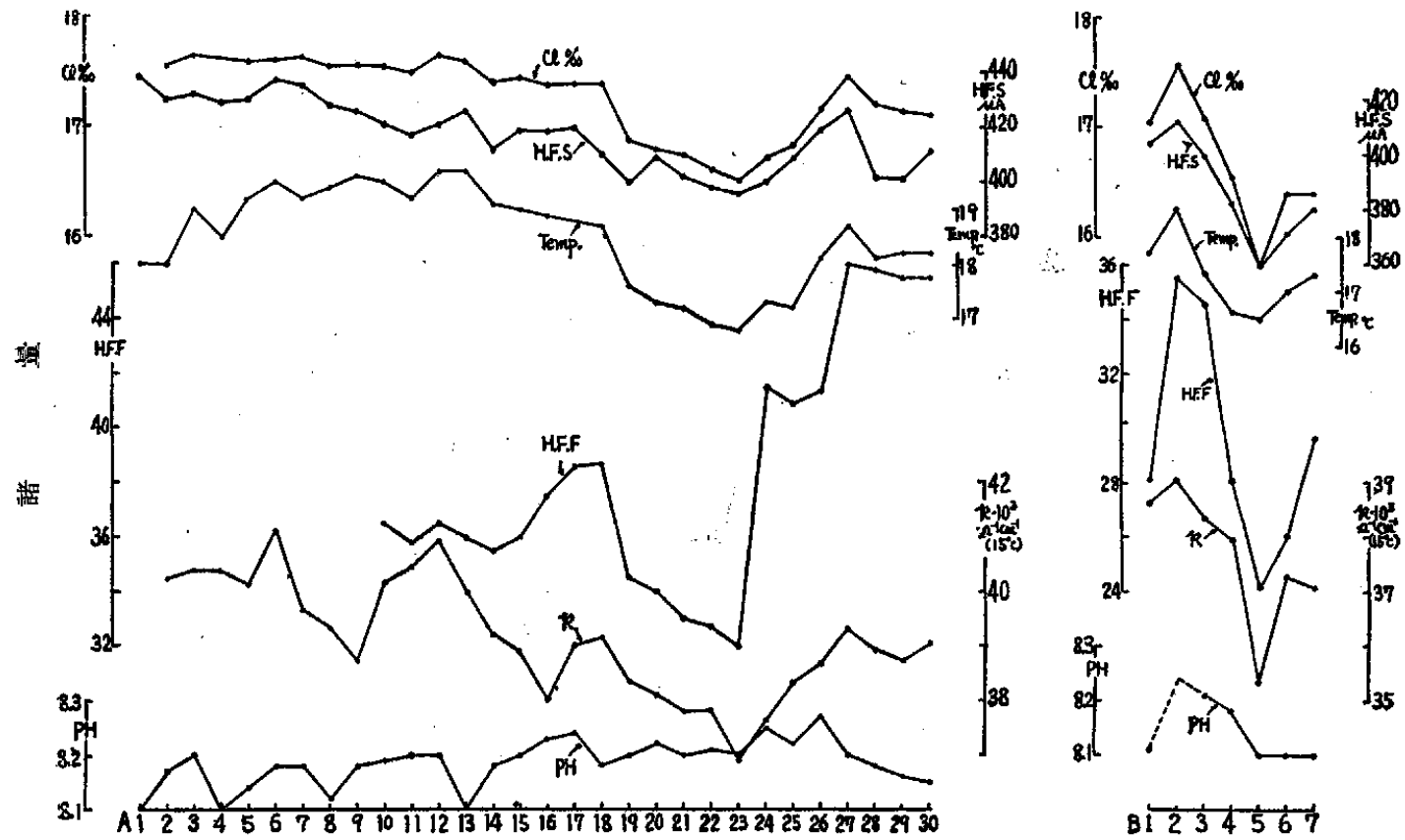

航跡図の位固の記量

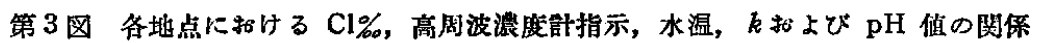

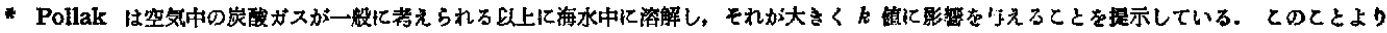

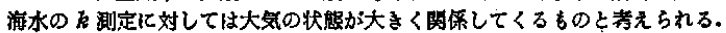


したととなならびにその測定操作よりくる実騟誤差のた めと考光られる。

\section{iii) H.F. (F). と水温の関保}

第 3 函の $\mathrm{Cl} \%$ と水温とはおおよそ比例的に变化して

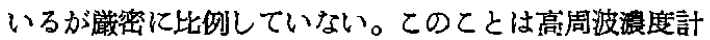
指示值 (H.F.) が $\mathrm{Cl} \%$ と水温との函数関保にあるの であって，壾録絓上にはこの両者の変化の合計が H.F. 値として得られるためとみなし得る。因みに著者らは 1 種類の海水より簡単な温度俰数を実験的に求め, 全体に わたって適用を試みたとてろ，全く予期に反する結果を 得た。てれらの結果より洘えて水温の項を含んだ記録結 果を得るためには，Jacobson*の武みたように多くの

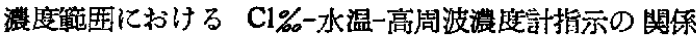
を実験的に求め，水温と高周波懐唐計指示の間にサ一ボ 機構的な機械的および嚚機的な考察を必要とするであろ う。

\section{iv) H.F. (F). と $\mathrm{pH}$ の阅係}

第3 図に示されるように $\mathrm{Cl} \%$ と $\mathrm{pH}$ 測定值の間にお いては、なんら特記すべき関係が認められない。てのと とは海水の大きな緩衔能力を物語っている。

\section{v) 湖定結果に対する海洋学的考察}

大挭湾における環流の方向は, 征来より第 1 図に点線

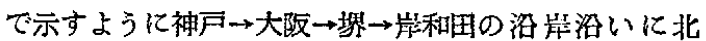
より南へ環状に流れのあるととが知られている。第 3 园 亿示した Cl\%，H.F.(F)., H.F.(S)., $k$, 水温の測定 值が A-23，24，B-4，5 の位置において最低㑷を示す ことは大阪湾に流入する湜川その他の阪神間の河川から の河川水と海水との混合する海域に相当しているととる 示している。ての海域における実際の記録結果の一例を 第4 図に示す。とのような H.F. (F).と Cl\%との間 の大きな異常性走す地点は， $\mathrm{Cl} \%$ の分布汃ら判断し て潮目に当っていると考えられる。A-15,〜A-18 では Cl\% がほとんど同一であるにも猢わらず，H.F. (F). では次第に增加して，A-19 亿至ると州者ともに急減し ている。また A-23,〜A-27 では $\mathrm{Cl} \%$ 方除々に堌加し ているのに反して, H.F. (F).では急增している。ての ことは潮目において $\mathrm{Cl} \%$ ではあまり明膯でないにも拘 わらずH.F.(F). においては著しい変化を示し，潮目付 近では $\mathrm{Cl} \%$ に現われないが，H.F.(F). 亿感度のある ものが存在しているととを示している。すなわち河川水 と海水との温合域では単に海水と河川水との混合による

- Jacobson は広箱囲な $S$ 名の海水について $S$ 路-水溫・ $\boldsymbol{k}$ の関係

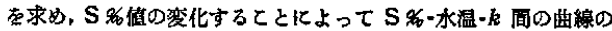
愐度が変るとをを示している。
$\mathrm{Cl} \%$ の变化のみでなく, 河川水により運搬された無機的 あるいは有機的物䝷か海水と接触するととによりあるる のはコロイド状となり，あるいは凝固したりなどして浮 遊しとれらが潮目付近に集っているものと考えられる。 つき第 5 図に大和川沖に停泊中の記録結果を示す。

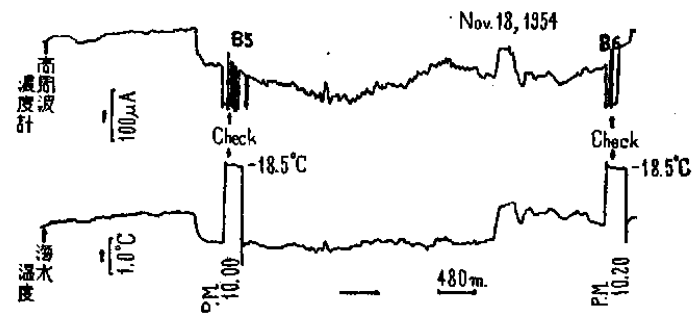

第 4 四大和川河口付近の高周波荟度計の 指示値と水温の自動凯録図

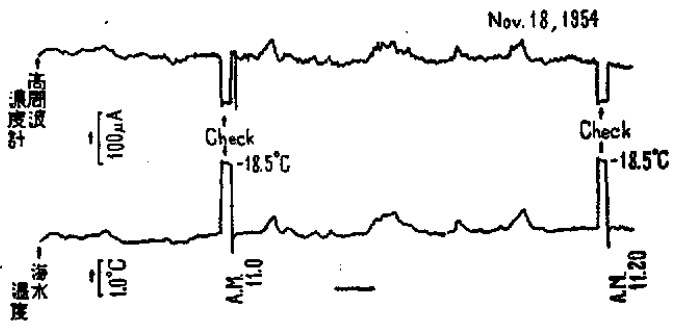

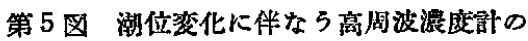
指示值と水温の自動叟録図（1）

当日の潮位は第 6 四に示したように，測定中は涱潮期 に相当し測定記録は，濃度計温度計ともに良く一致した 比例関係を保ちながら不規則な㤎化を示している。ての ことは潮位の变化と共に移動する海水の変化を示すもの で，干潮時にての位置を占めていたでく沿岸の海水が， 除々に银潮期に移るにしたがって次第に沖合の海水と交 代してゆく過程を示し，細かな変化があるが㴖潮時に近 付くと沖合のやや一様な海水によって占められて，その 記録結果は第7四のように H.F. (F).および水温共に 平坦な直線となってくる。

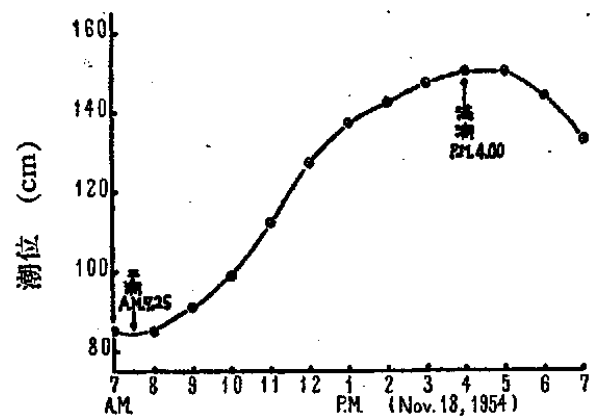

第 6 図昭和 29 年 11 月 18 日の時刻 
Nov 18,1954

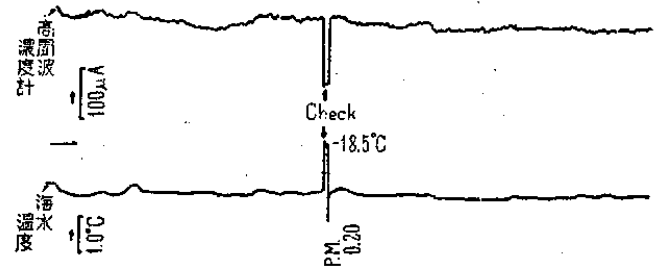

第 7 図 潮位变化に伴な5高原波濃庭計の 指示值と水温の自動祀録図

(2)
以上高凬波濃度計の海水㙁分濃度連続記録測定に対す る適用性について行った考察および央験とその結果につ いての詩議なのべた。要約すれば，i）過去において行 われた $k$ の連続测定による $\mathrm{S} \%$ の連続決定と同様に高 間波濃庢計の適用が同じ目的に対して可能である。ii ） 高周波濃度計の場合 S\%のみならず，有機物および微
細な固形物等に対しても鋭敏な㭘胿能力を示し，異なっ た意昧で広沈な適用性が洘えられる。iii） S\%がその海 水の水温と函数器係にあるため, 水温の測定を並行して 行うとともに，高周波湌度計の指示が水温の項を含んだ ものとして指示されるように，潧度訫と温度計の間にサ 一ボ機構的な機械的，電機的連結を必要とする。iv) 実 験によって得られた眮定結果が良来より知られている海 洋学的知見とよく一致する。

終りに望み，本实験に際して終始御健宜を睗わった神 戶海洋䒝象合辰松平康男博士ならびに多忙をさいて御協 カ下さった同台㿥湘船春風丸川池 宽船長始め乘組員一 同の方々，扎よび装置の運般，装倩に御協力下きった大 阪府立大学工学部店用化学利分析化学教室の大学院学生 および卒業研笲生の方々に深く謝䉥を表わす。本䂨究の 货用の一部は交部雀科学砳究費によった。

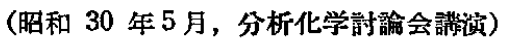

（東北大学理学部化学教室，倠台市）（昭和 30 年 7 月 14 日受理）

\section{微量重金属の抽出におよぼす pH および共存塩類の影響 （その 1) ジチゾンー四塩化㟒素-亜鉛系の抽出曲線について (生物体中の痕跡元秦の分析法に関する研究 (第 7 報))*}

小川欣也

\section{1. 緒壱}

たとえばシチゾン，オキシン等の有機試薬による溶媒 抽由は微量重金属の分離および定量に重要な役割をむっ ているにもかかわらずててれらの試薬は特殊性にとぼし く、てれが大きな欠点となっている。ての閒題は多くの 研究者により，嶾蔽绪の使用， $\mathrm{pH}$ の調整，溶媒の変蕌 等によって部分的认は一応解決された1。しかし Wich一 mann2), Irving ${ }^{3)}$ らも指摘しているように，基礎的な

* 前報 (第6 報) 山本, 本赫 76, 1202 (1955). 本報文は東北大学 箱守研究室の一連の研究の一つである.

1) E. B. Sandell, "Colorimetric Determination of Traces of Metals" (1950) New York; A. Martell, M. Calvin, "Chemistry of the Metal Chelate Compounds" p. 451 (1952) New York.

2) H. Wichmann, Ind. Eng. Chem. Anal. Ed. 11, 66 (1939).

3) H. Irving, R. J. P. Williams, J. Chem. Soc. 1949, 1841.
立場から完全な研究を行うととが必要であると考光，著

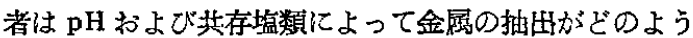
亿影響されるかを検討し，合せて微量重金属の適当な分 析法を見归さんとした。本報ではジヂンー四塩化炭素一 悪鉣系で通常の綏衙液，亜鈶以外の金属の隱蔽剂として 用いられる塩わよびその他の二，三の塩類が共存する場 合の抽屾曲線について娭討した結果を報告する。

\section{2. 試莯および装置}

試 莱：亜鈶の標準溶液は硝酸西銛苍熱分解して精製 した酸化亜鈶を蒸留塩酸にとかし $1 \mathrm{~N}$ 酸性とする(921 r /cc)。乙れを適㭙うすめて 使用する。ジゾンー四塩化 宸素溶液 $(15.42 \gamma / \mathrm{cc})$ は内藤氏の文献》により精製し，

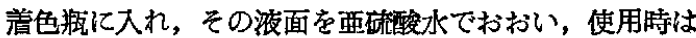
再蒸留水で 2,3 回洗浄して用いた。銀福準溶液で䅺定し

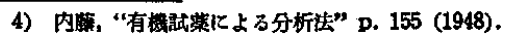

